\title{
HTLV Tax-1 and Tax-2 proteins enhance interferon regulatory factor 3 dependent promoter activation
}

\author{
Erica Diani, Francesca Avesani, Giorgia Cremonese, Elisa Bergamo, Umberto Bertazzoni, Maria Grazia Romanelli* \\ From 16th International Conference on Human Retroviruses: HTLV and Related Viruses \\ Montreal, Canada. 26-30 June 2013
}

The HTLV-1 infection is known to induce an alteration of type I interferon (IFN-I) signaling since it is capable of escaping IFN-mediated immune response in vitro and Tax-1 protein modulates the expression of factors involved in the interferon signaling. In the present study we have investigated the effect of Tax-1 and Tax-2 expression on the activation of an IFN-regulatory factor 3 (IRF3) regulated promoter through the recruitment of the IFN-I upstream IKK $\varepsilon$ and TANK-binding kinase 1 (TBK1) factors, two IkBrelated kinase homologues, which are essential for the activation of IRF3 pathway. We have demonstrated that both Tax-1 and Tax-2 were detectable in immuno-complexes formed by IKK $\varepsilon$ and TBK1 in HEK 293T transfected cells, but did not interact with the IRF3 factor. The presence of Tax-1 and IKK $\varepsilon$ in transfected cells resulted in a significant activation of the IRF3 regulated promoter. A similar effect was measured in the presence of Tax-1 and TBK1. We have also observed that Tax-1 mutants defective in sumoylation and ubiquitination post-translational modification were impaired in their ability to form complexes with IKK $\varepsilon$ or TBK1 and in the transactivating activity on IRF3 dependent promoter.These data provide evidence for a role of Tax proteins in the activation of IFN-I pathway, mediated by interaction with IKK $\varepsilon$ and TBK1 kinases. The effects of the Tax interaction with factors that act upstream of interferon regulatory factor IRF3 should be taken into account to further explain the IFN-mediated immune response to HTLV-1 infection. This study is funded by AIRCCariverona.

Published: 7 January 2014

* Correspondence: mariagrazia.romanelli@univr.it

Department of Life and Reproduction Sciences, Section of Biology and Genetics, University of Verona, Verona, Italy

(0) 2014 Diani et al; licensee BioMed Central Ltd. This is an Open Access article distributed under the terms of the Creative Commons Attribution License (http://creativecommons.org/licenses/by/2.0), which permits unrestricted use, distribution, and reproduction in any medium, provided the original work is properly cited. The Creative Commons Public Domain Dedication waiver (http:// creativecommons.org/publicdomain/zero/1.0/) applies to the data made available in this article, unless otherwise stated.
doi:10.1186/1742-4690-11-S1-P97

Cite this article as: Diani et al:: HTLV Tax-1 and Tax-2 proteins enhance interferon regulatory factor 3 dependent promoter activation. Retrovirology 2014 11(Suppl 1):P97.

Submit your next manuscript to BioMed Central and take full advantage of:

- Convenient online submission

- No space constraints or color figure charges

- Immediate publication on acceptance

- Inclusion in PubMed, CAS, Scopus and Google Scholar

- Research which is freely available for redistribution
- Thorough peer review 